\title{
Willingness to Communicate in the Second Language: Understanding the Decision to Speak as a Volitional Process
}

\author{
PETER D. MACINTYRE \\ Department of Psychology \\ Cape Breton University, PO Box 5300 \\ Sydney, Nova Scotia \\ Canada B1P 6L2 \\ Email: peter_macintyre@cbu.ca
}

\begin{abstract}
Previous research has devoted a great deal of attention to describing the long-term patterns and relationships among trait-level or situation-specific variables. The present discussion extracts kernels of wisdom, based on the literatures on language anxiety and language learning motivation, that are used to frame the argument that choosing to initiate communication at a particular moment in time can be conceptualized as a volitional (freely chosen) process. The result is a degree of willingness to communicate (WTC) with the potential to rise and fall rapidly as the situation changes. Previous research based on both qualitative and quantitative methodologies is described that demonstrates the complexity of the processes involved in creating WTC. It is argued that methodologies must be adapted to focus upon the dynamic process of choosing to initiate or avoid second language communication when the opportunity arises.
\end{abstract}

\section{WHEN PRESENTED WITH AN OPPORTUNITY} to use their second language (L2), some people choose to speak up and others remain silent. Why is it that, even after studying a language for many years, some L2 learners will not turn into L2 speakers? It is not a simple question when one takes into consideration the various relevant individual, social, linguistic, situational, and other factors. This article examines the phenomenon of reluctant speakers as an example of a volitional process, using Willingness to Communicate (WTC) as a central concept. Previous research in second language acquisition (SLA) has not examined the convergence of psychological processes underlying communication at a specific moment. For example, an experienced learner who is unwilling to communicate might show both high motivation for learning and high anxiety about communicating.

The Modern Language Journal, 91, iv, (2007)

0026-7902/07/564-576 \$1.50/0

(C)2007 The Modern Language Journal
Is such a person willing to communicate? If not, can we find the conditions under which he or she would be willing to speak up? The concept of WTC, defined as the probability of speaking when free to do so, helps to orient our focus toward a concern for micro-level processes and the sometimes rapid changes that promote or inhibit L2 communication.

The origins of the WTC construct lie in the first language (L1) communication literature (McCroskey \& Baer, 1985; see also Burgoon, 1976, on unwillingness to communicate). WTC offers the opportunity to integrate psychological, linguistic, educational, and communicative approaches to L2 research that typically have been independent of each other. WTC may be seen as both an individual difference factor facilitating L2 acquisition, especially in a pedagogical system that emphasizes communication, and as a nonlinguistic outcome of the language learning process.

Given that WTC might not be as familiar as other individual difference factors, let us 
approach the concept from two more familiar points of departure, research on language anxiety and on motivation. In briefly reviewing each concept, I will both anchor the conceptualization of WTC and extract kernels of wisdom for use in conceptualizing the processes underlying communication.

\section{LANGUAGE ANXIETY}

Language anxiety captures the worry and usually negative emotional reaction aroused when learning or using an L2. After a period of some conceptual difficulties and ambiguous empirical results (see reviews by MacIntyre, 1999; Scovel, 1978; Young, 1991), it would appear that SLA researchers have settled on the idea that language anxiety is an emotional experience uniquely provoked by L2 situations (Horwitz, Horwitz, \& Cope, 1986). A key to the conceptual clarification in this area lies in the distinctions among trait, situation-specific, and state levels of conceptualization, each of which provides a valuable, but somewhat different perspective on the processes under study. At the trait level, the concern is for concepts that endure over long periods of time and across situations; at the trait level the concern is for finding and establishing broad, typical patterns of behaviour. At the situation-specific level of conceptualization, the concern is for concepts that are defined over time within a situation; at the situation-specific level, the concern is for establishing specific, typical patterns of behaviour. At the state level, the concern is for experiences rooted in a specific moment in time without much concern for how frequently those experiences occurred in the past or whether they might occur again in the future. We might know a neurotic person who seems anxious at all times, or a person bothered by speaking in the L2 but not in the L1, or a person feeling nervous right now. Respectively, these are examples of trait, situationspecific, and state anxiety. All three levels of conceptualization appear in the literature, and each has an important role to play in understanding the language learning process.

Early research appeared to show an inconsistent relationship between anxiety and language learning (Scovel, 1978). The problem appears to have been the level of conceptualization of anxiety. Several studies have been conducted with trait, state, and situation-specific measures of anxiety. It is clear that, on the one hand, measures of trait-level anxiety (for example, Spielberger's, 1983, Trait Anxiety Scale) and measures of anxiety that are not specifically related to language learning or usage (such as test anxiety) do not show a consistent correlation with measures of L2 performance (see MacIntyre \& Gardner, 1989; 1994a). On the other hand, situation-specific measures of language anxiety (e.g., the Foreign Language Classroom Anxiety Scale, Horwitz et al., 1986) are quite reliably, negatively related to a wide variety of measures of L2 performance (Aida, 1994; Frantzen \& Magnan, 2005; Gregersen, 2003; Horwitz, 1986; MacIntyre \& Gardner, 1994a; Onwuegbuzie, Bailey, \& Daley, 2000; Vogley, 1998). Finally, state anxiety has not been widely studied in SLA, but the available results appear to show that if anxiety is aroused, L2 performance suffers (Allen \& Herron, 2003; Gregersen, 2003; MacIntyre \& Gardner, 1994b). The study of state anxiety is made more complex by learners' active attempts to cope with and compensate for the effects of anxiety, and by the relatively automatic process of habituation that lessens the emotional arousal as time goes by.

The process of adapting to anxiety, through active coping or simple habituation, suggests that descriptions of language anxiety and the processes by which it affects language learning should be sensitive to fluctuation over short periods of time. These fluctuations are lost when anxiety is defined only at the level of a personality trait. A focus on its fluctuations presents an opportunity to examine both the felt experience of language anxiety (see Price, 1991) and the physiological processes that underlie it (see Schumann, 1997; Schumann et al., 2004).

This observation leads to the first kernel of wisdom that we can extract from the literature: The relationships among variables under study in SLA may change substantially when concepts are defined at different levels of abstraction (e.g., state, situationspecific, or trait levels).

\section{MOTIVATION}

The second conceptual point of departure for this discussion is motivation. Gardner's (1985) socioeducational model, with its focus on integrative motivation, has been considered the dominant model in the field for many years. However, Crookes and Schmidt (1991), Dörnyei (1994), Oxford and Shearin (1994), and others have been critical of its influence and called for reopening the research agenda on motivation over a decade ago. At the moment, research into language learning motivation is flourishing with developments, including Dörnyei's (2005) process model and L2 possible self model, Noels's (2005) work on self-determination, Schumann et al.'s (2004) 
physiological approach, Ushioda's (2001) qualitative approach to learner autonomy and Yashima, Zenuk-Nishide, and Shimizu's (2004) concept of international posture. We should not, however, lose sight of the socioeducational model because there are is still much to be learned from it.

The socioeducational model captures a set of 11 interrelated concepts (Gardner, 2001). Figure 1 shows the basic model. Integrativeness refers to a complex set of attitudes that reflect a genuine desire to meet, communicate with, and possibly identify emotionally with another group (Gardner \& Lambert, 1972). Attitudes toward the learning situation reflect the attitudes that language students have toward their teacher and the course. Finally, motivation is the engine that drives the system, reflecting the notion that a truly motivated student shows a desire to learn the language, expends effort in learning, and enjoys the task (Gardner, 1985). Therefore, integrative motivation is a complex set of attitudes, goal-directed behaviours, and motivations. The focus on establishing a relationship with members of another language group, that is, creating "real bonds of communication with another people" (Gardner, 2001) is what separates the integrative motive from other motivational processes that also have an impact on language learning.

In the original article leading to the socioeducational model, Gardner and Lambert (1959) hypothesized that "a strong motivation to learn a second language follows from a desire to be accepted as a member of the new linguistic community" (p. 272). After almost 50 years of research, and over 75 studies published by Gardner and associates, it is clear that the intergroup features of language provide significant support for the motivation to learn
(Masgoret \& Gardner, 2003). Intergroup attraction, in some form, develops in diverse language learning contexts and has been captured by concepts such as international posture (Yashima, 2002), xenophilic and sociocultural orientations (Clément, Dörnyei, \& Noels, 1994), acculturation processes (Schumann, 1986), and interest in the target language and people (Ushioda, 2001). The importance of the target language group in SLA has been repeatedly confirmed (Allard \& Landry, 1994; Clément, 1986; Giles \& Byrne, 1982; Noels, 2001; Spada, 1986). Given findings consistent with prior research that show strong student interest in the communicative and instrumental aspects of language learning, Alalou (2001) reported an "overwhelming demand for communication skills" (p. 465) among students in Spanish, French, and German language programs at a large U.S. university.

In highlighting the motivational supports that are relatively unique to the language learning process, we may extract a second kernel of wisdom: The major motivation to learn another language is to develop a communicative relationship with people from another cultural group.

\section{THE ISSUE OF TIME}

Whereas the literature on the role of the intergroup context in SLA is well developed (see Clément \& Gardner, 2001; Masgoret \& Gardner, 2003), the literature on other L2 motivational perspectives is newer and more sporadic in its empirical support. Space does not permit a review of these developments here (but see Dörnyei, 2005), though it is clear that motivation is being examined from a number of exciting, and at times incompatible, perspectives. In examining the issues

FIGURE 1

Gardner's Socioeducational Model

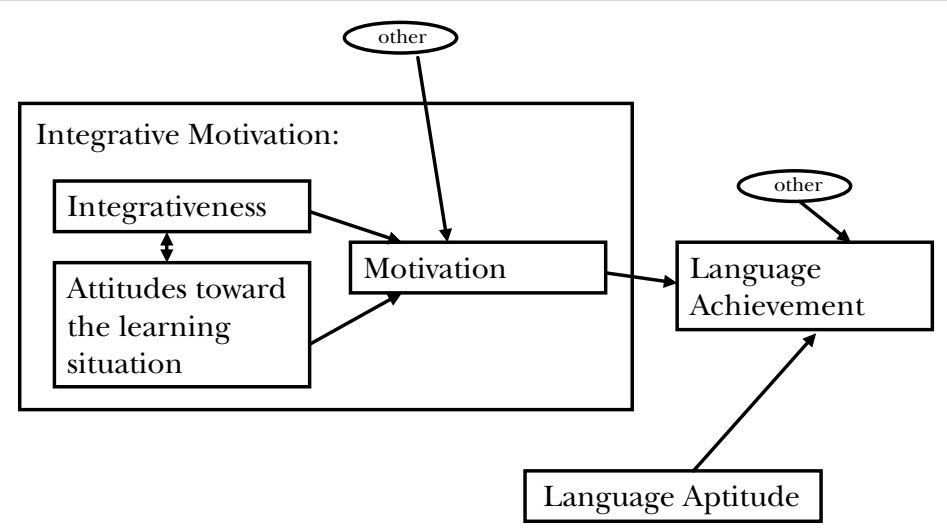


raised in the debate on reopening the research agenda for motivation, and subsequent lessons learned, Dörnyei (2003) commented:

I have now come to believe that many of the controversies and disagreements in L2 motivation research go back to an insufficient temporal awareness ... that different or even contradictory theories do not exclude one another, but may simply be related to different phases of the motivated behavioral process. (p. 18)

In discussing the process model, Dörnyei (2001, 2005) made an important distinction between motivation to enter a situation and motivation to engage in effortful, task-related behaviour within the situation (see also Jülkunen, 1989, 2001). Dörnyei (2005) highlighted the different motivational processes that occur before, during, and after a specific event. Motivational processes also can be grouped at various levels (Dörnyei, 1990), including those that emphasize the enduring social context (e.g., the integrative motive) or those that emphasize localized events (e.g., task motives).

These points lead to a third kernel of wisdom: The manner in which motivation affects language learning changes as the time frame under study changes.

\section{CROSSING THE RUBICON}

The issue of time, which is so important for future theory development, arises in an interesting way within Dörnyei's (2005) process model. The model proposes that individuals reach a decision point that Dörnyei calls crossing the Rubicon where a language learner commits to taking action. For those readers unfamiliar with the phrase, the Rubicon was an ancient river separating the Roman Province of Cisalpine Gaul from the heartland of Rome. By law, no Roman general could lead his army across that river toward Rome-to do so was considered an act of war against Rome itself. In 49 BC, after some hesitation, Julius Caesar crossed the Rubicon, initiating an irrevocable and dangerous course of action that led to civil war and eventually the installation of Caesar as the ruler of Rome. Crossing the Rubicon is a powerful metaphor for passing the point of no return, one that captures the essence of the sometimes conflicted decisions that language learners must make on a regular basis: (a) Do I raise my hand to answer a question in the classroom? (b) Do I offer assistance to an L2 speaker I just met at the airport? (c) Do I try to use the L2 in an actual conversation, not knowing exactly what course it might take or what embarrassment awaits?
The motivational tendencies that are captured by various theories, such as interest in communicating with another language group, deciding to study an L2, and engagement with language tasks, are played out daily in specific actions we takethe decisions we make about what we are willing to do. Application of this focus to language learning implies a potential new direction for research concentrating on the interaction of various processes at a specific moment in time. For example, we might focus on the conflicted moment when high motivation for language learning propels a learner toward communication but high anxiety arousal restrains his or her action.

If we consider the interaction of motivation (approach) and anxiety (avoidance), we arrive at what might be the critical decision for language learning success: Does a learner choose to communicate when the opportunity arises? This question bridges the social processes of interpersonal and intergroup contact, the educational process of language learning, as well as interpersonal communicative processes. The question has a clear temporal focus on a specific moment. Defined as the probability of initiating communication, given choice and opportunity, WTC integrates motivational processes with communication competencies and perceived selfconfidence.

\section{WILLINGNESS TO COMMUNICATE}

The kernels of wisdom described previously, including the level of conceptualization, intergroup communication processes, and the issue of time, have been integrated into the pyramid model of WTC (MacIntyre, Clément, Dörnyei, \& Noels, 1998). Constructs commonly employed in the L2 literature are layered according to a proximaldistal continuum (see Figure 2) that captures the dimensions of time and concept specificity, with a distinctly intergroup flavour. Significant elements of the most distal factors in the model (Layer VI), intergroup climate and personality, exist even before the individual is born because they capture enduring intergroup and genetic influences handed down from one generation to the next. The individual has little influence over these factors, and generally he or she plays a somewhat indirect role in language behaviour. The next layer (V) of the pyramid captures the individual's typical affective and cognitive context. Setting the tone for motivation to learn the L2 is the tension between a desire to approach the target language group and a sense of hesitation or fear of the implications of doing so. The last of the 
FIGURE 2

The Pyramid Model of Willingness to Communicate

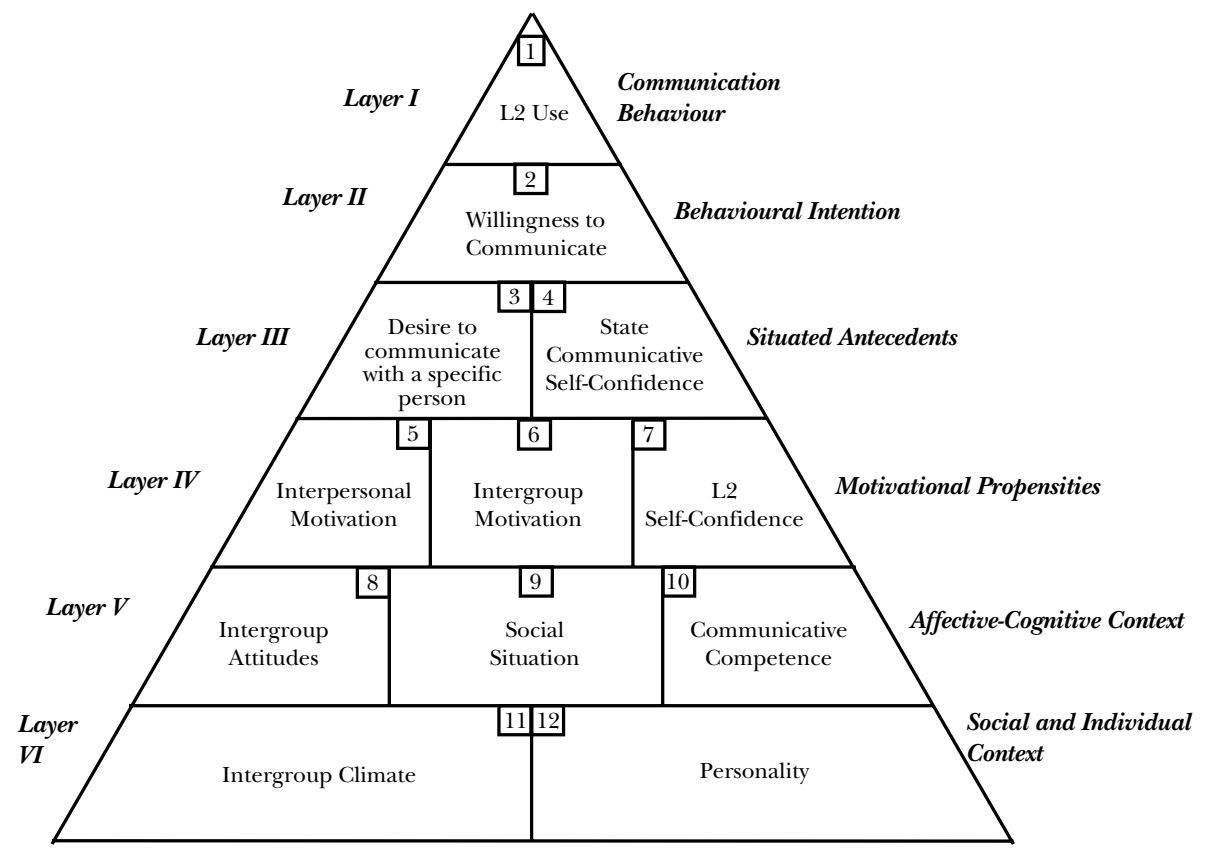

Note. From "Conceptualizing Willingness to Communicate in a L2: A Situational Model of L2 Confidence and Affiliation," by P. D. MacIntyre, R. Clément, Z. Dörnyei, and K. Noels, 1998, Modern Language Journal, 82, p. 547. Reprinted with permission.

layers of enduring influences (Layer IV) contains highly specific motives and self-related cognition. Intergroup motives stem directly from membership in a particular social group, and interpersonal motives stem from the social roles one plays within the group. Issues of affiliation and control (broadly defined) are the most basic of motives, exerting their effects throughout the system. This layer shows that roles and motives combine with L2 self-confidence that represents perceptions of communicative competence coupled with a lack of anxiety.

When we move to Layer III of the pyramid, a transition is made from enduring influences to situational ones. The sense of time is coming to focus on the here and now. At this level of the pyramid model is the desire to communicate with a specific person as well as a state of self-confidence. The culmination of the processes described thus far is variation in the WTC, to initiate L2 discourse on a specific occasion with a specific person, remembering that the person represents a different social group. This level of the model represents the level of behavioural intention (Ajzen \& Fishbein, 1980) to speak, if one has the opportunity, or to remain quiet. This moment is akin to "crossing the Rubicon," the point where one commits definitively to act in the L2. At times, one crosses such a threshold in the flow of conversation mindlessly without hesitation or concern; at other times, L2 communication is initiated with reluctance, hesitation, even trepidation. The most proximal factor, WTC (Layer II), represents the final psychological step in preparation for L2 communication. In effect, the time has come to take action-Am I willing to initiate communication, or am I choosing to remain silent? This is a moment that we must better understand.

The issue of time raised by Dörnyei (2003) is addressed here in two ways. First, the original WTC construct (McCroskey \& Richmond, 1991) was a trait-level variable, representing a stable tendency to approach or avoid communication. Such a concept does not necessarily require the availability of any specific opportunity it requires simply a predisposition to communicate should the opportunity arise (MacIntyre \& Charos, 1996). For McCroskey and associates, and in several studies done on L2 learners (e.g., MacIntyre, Baker, Clément, \& Donovan, 2002), WTC is a trait-like characteristic carried from one situation to another. However, in the pyramid model, L2 WTC is not conceptualized at the trait level, but rather as a state. WTC is a state of readiness occurring in 
the present moment. Its immediate influences are a state of self-confidence (defined by low anxiety and a perception of L2 competence) and a desire to communicate with a specific person. This conceptualization suggests that the initiation of communication is a matter of choice, a decision to be made at a particular moment. Choosing to communicate in the L2 is an act of volition.

\section{VOLITION}

The great American psychologist and philosopher James (1890) had a brilliant passage on volition in which he wrote:

We know what it is to get out of bed on a freezing morning in a room without a fire, and how the very vital principle within us protests against the ordeal. Probably most persons have lain on certain mornings for an hour at a time unable to brace themselves to the resolve. We think how late we shall be, how the duties of the day will suffer; we say, "I must get up, this is ignominious," etc; but still the warm couch feels too delicious, the cold outside too cruel, and resolution faints away and postpones itself again and again just as it seemed on the verge of bursting the resistance and passing over into the decisive act....

Now how do we ever get up under such circumstances? If I may generalize from my own experience, we more often than not get up without any struggle at all. We suddenly find that we have got up. A fortunate lapse of consciousness occurs; we forget both the warmth and the cold; we fall into some revery connected with the day's life, in the course of which the idea flashes across us, "Hollo, I must lie here no longer"-an idea which at that lucky instant awakens no contradictory or paralyzing suggestions, and consequently produces immediately its appropriate motor effects....

It was our acute consciousness of both the warmth and the cold during the period of struggle, which paralyzed our activity then and kept our idea of rising in the condition of wish and not will. The moment these inhibitory ideas ceased, the original idea exerted its effects.

This case seems to me to contain in miniature form the data for an entire psychology of volition. (pp. 524525)

A significant number of L2 learners around the world brace themselves to the resolve, they learn another language, and they choose to speak in that language. For such people, a state is reached in which L2 communication is approached willingly; but as James (1890) suggested, others seem destined to remain in the condition of wish and not will.

Perhaps the most interesting behaviours are those that are freely chosen, that is, volitional. The study of volition in psychology dates back to the very beginning of the discipline. However, the concept was all but abandoned as motivation research moved in the direction of what seemed to be more philosophically solid concepts such as drives and instincts because volition, free will, and similar concepts have been extraordinarily elusive. Such concepts beg difficult questions, including "Where does free will come from?" This sort of question can lead into an intellectual quagmire that might be better left undisturbed for this article in favor of extracting the theoretical value contained in the idea of volitional action. James's (1890) passage just quoted eloquently describes the convergence of past and future influences on the present moment. The concept of volition has the potential to organize multiple, competing motivational, cognitive, and affective influences on specific observable actions by the learner.

Models of motivation in psychology, and models of L2 learning motives, often employ concepts rooted in the learners' past (e.g., attained proficiency, prior intergroup conflict, and existing personality traits) or in the learners' future (e.g., plans and goals, possible selves, and language learning orientations). Yet, to understand how motivational processes have an effect on actions such as communicative behaviour, one must study the moment in which they are applied. The process of exercising volition provides a way to specify how motivational tendencies are enacted in the moment-to-moment choices we make, such as choosing to speak up or to remain quiet.

Whereas most research on WTC has taken the trait perspective, a few studies have examined the choice to speak. Four such studies will be highlighted, including experimental and qualitative methodologies, as well as a combination of L1 and L2 communication.

MacIntyre, Babin, and Clément (1999) studied the WTC of people as they were communicating in their L1s, but the basic psychological processes apply to L2 communication as well. The study was based on research by Zakahi and McCroskey (1989), who found that $92 \%$ of the respondents who scored high on the WTC scale were willing to participate in a communication laboratory study, but only $24 \%$ of those who scored low on the scale were willing to participate. In this case, the dependent variable was simply whether or not the participant showed up, no speaking was required. MacIntyre et al. (1999) replicated and extended Zakahi and McCroskey's study by pretesting a group of participants during a regularly scheduled psychology class, with the invitation to everyone who was willing to come to a communication 
laboratory for the second part of the study. Once the research participants were in the lab, they were asked to decide whether or not to engage in specific oral and written communication tasks (similar to the well-known Can Do tasks, see Clark, 1981) that were either easy or difficult. The results showed that the participants who attended the laboratory portion of the study had significantly higher WTC than those who chose not to attend. Among those who visited the laboratory, the WTC scores predicted the initiation of both oral and written communication tasks; neither anxiety nor perceived competence was related to the initiation of oral communication. This finding is evidence for the conceptual differentiations among the concepts, as well as strong empirical support for the key defining characteristic of WTC, choosing to initiate communication when there is a choice.

A more recent study (MacIntyre, Clément, \& Noels, 2007) was conducted among L2 learners at the high school level. The research examined the role of personality traits, specifically extraversion, in vocabulary learning and in the decision to initiate communication using the new vocabulary words. Approximately half of the learners studied the new vocabulary items alone, and the other half studied in small groups. The situation in which students were studying had a significant impact, but it was not as straightforward as might be anticipated. It is known from prior research that introverts learn better in familiar situations than extraverts (Wilson \& Lynn, 1990) because, generally, introverts seem to prefer routine (Eysenck \& Zuckerman, 1978; Wilson, 1978). The reverse is true for novel situations-extraverts like a little change (Ahmed, 1990). When the data were reexamined using the familiarity of the study situation, an interesting pattern of results was found. As expected, the extraverts showed higher WTC than the introverts when studying new L2 vocabulary words in a moderately unfamiliar situation. However, the pattern was reversed when the study conditions were highly familiar. Under that condition, the introverts actually showed higher WTC than the extraverts did. Results such as these attest to the complexity of studying the volitional choices of the moment.

Two studies based on qualitative data, one published and one unpublished, in which the "focused essay" technique (MacIntyre \& Gardner, 1991) was employed, have given insight into the thought process behind initiating L2 communication. For a focused essay, a respondent is asked to write a few lines about a specific event in some detail. In this case, the respondents were asked for a description of a time when they felt "most willing" and another time when they felt "least willing" to speak in their L2s.

The first study (Baker \& MacIntyre, 2000) examined over 200 English-speaking students learning French as an L2 in an English-speaking community in Canada. Some students were from standard French classes and others from a Frenchimmersion program in which all courses are taught in French (except their English course). In describing a situation in which they were highly willing to communicate in French, the nonimmersion students seemed very pleased with small, specific successes (e.g., giving directions, meeting a Francophone, traveling). For example, one student said:

My father has a tailoring and bridal shop ... and one day a French-speaking lady came in and my Dad's wife can speak French but she was off that day, so I was able to help her [the lady] out enough so that she would come back. (p. 331)

The immersion students seemed to have less strong emotion behind their high WTC, having used the language with Francophones, their friends, and in giving classroom presentations. The immersion students seemed impressively nonchalant about situations of high WTC.

When describing an event associated with low WTC, the immersion students described much stronger emotions than the nonimmersion students. In both groups of students, the type of event that led to low WTC was an interaction in which, after the respondent initiated communication in French, the interlocutor switched to English. This is an embarrassing rejection of the volition of the speaker initiating communication in the L2; to quote James (1890), "it is ignominious!" (p. 524). In the students' minds, the rejection of their self-presentation negatively affected communication, reducing their WTC. The students reported strong emotion in this situation. It is interesting to note that the students who described such an event indicated that it provided increased motivation for future language learning.

A second set of qualitative data (MacDonald, Clément, \& MacIntyre, 2003) was collected in Ottawa, Ontario. Ottawa is a bilingual city, and the University of Ottawa where the research was conducted functions as a bilingual institution. We requested focused essays from over 100 Anglophone and Francophone university students. It is usually the case in Ottawa that Francophones have more experience speaking in English than Anglophones have speaking in French. 
Our data showed that the Anglophones were most willing to use French in situations where the only other choice was to refuse to speak at all. The most frequently cited situation was when a Francophone person requested assistance (more than one in four responses fit this category), yet the person seeking help was expected to speak English if possible. The Anglophones also mentioned error correction quite often (about $20 \%$ of the responses), both as something that increased and as something that decreased their WTC, depending on whether it was expected and how it was offered.

I'd be most willing if I had friends around me. I always felt comfortable in a classroom giving a speech. When you are out of the classroom I feel like people are analyzing me. I don't mind when a teacher does it, but not an acquaintance. (p. 10)

Among the Francophones, over one third of the respondents were highly willing to communicate in English with friends and in peer groups where other people felt more comfortable in English, and a similar number described situations where another person needed assistance in English.

For low-WTC situations, we saw a sharp contrast between Anglophone and Francophone responses. The Anglophones were least willing to speak when they felt a lack of self-confidence or when speaking with strangers (over 20\% each). Several Anglophones felt they were being analyzed and critiqued by interlocutors, especially for accent and grammatical errors. Self-consciousness seemed to play a major role for the Anglophones. This is the sort of mindset James (1890) described as lying in bed on the freezing morning, where contemplating attributes of the situation interfere with acting in that situation.

For the Francophones, a different type of situation typically was mentioned. Almost half the respondents said that they were least willing to speak English with Francophone family and friends. For many, it simply made sense to use French with Francophones. However, the Canadian political context was apparent in some of their answers, given that some Francophones felt the need to preserve the French language and to enhance its vitality. The Francophones also indicated an unwillingness to communicate on topics that were unfamiliar or that required specialized vocabulary, a much more specific type of situation than we observed among the Anglophones.

Quand je dois parler de sujets très précis où je ne suis pas certain de l'exactitude des termes. (When I must talk about precise things and I am not certain of the exact terminology.) (p. 26)

These four studies implicate many of the concepts noted in the introductory pages of this article. The results indicate that the influences of psychological, pedagogical, situational, linguistic, sociopolitical, and other considerations wax and wane in their impact at the specific moment when one decides to communicate or not.

These points lead to a fourth kernel of wisdom: Studying volitional choices demonstrates that opposing processes (e.g., approach and avoidance) converge to affect L2 communication.

\section{DRIVING AND RESTRAINING FORCES}

To help us better understand the processes, we turn to the classic social psychology/Gestalt psychology theory of Lewin (1951) who specifically addressed the issue of converging forces on social interaction. Lewin's field theory describes the energy and direction that may lead to action. In the Gestalt tradition, action is based on the totality of co-existing, mutually interdependent facts. Lewin divided influences into the general life situation (experiences, disposition) and the momentary situation, in a manner that we also used in our pyramid model (MacIntyre et al., 1998). Lewin also commented that the momentary influences have much greater significance for behaviour than the general life situation, which serves as background, and we also have adopted that perspective within the pyramid model of WTC. For example, any one of the elements of the pyramid that become salient at a particular moment may have an impact on behaviour. We see this impact in the qualitative data from Ottawa (MacDonald et al., 2003), for example, where social roles were foregrounded for some (e.g., error correction from teachers vs. acquaintances), and long-term goals were emphasized for others (repeat customers provide economic security for a small family business), whereas issues of self-confidence were most salient for a number of persons (knowing terminology before speaking).

In outlining motivational issues in Field Theory, Lewin (1951) proposed two types of forces: (a) driving forces (energy that is in the direction of the intended goal); and (b) restraining forces (energy that impedes the achievement of a goal by working in the opposite direction towards a different goal). Over 50 years ago, Lewin made the valuable observation that it is easier to modify a person's actions by reducing the restraining forces than it is by increasing the driving forces, 
an observation supported by Agazarian and Gantt (2003). This observation helps to explain why the Anglophone speakers in Ottawa (MacDonald et al., 2003) seemed to hold back from speaking French unless there was no other choice. The Francophones tended to have had more contact with Anglophones and higher competence in English, and therefore seemed to perceive fewer restraining forces.

Lewin's (1951) observations, along with the pyramid model for L2 communication, emphasize the moment-to-moment dynamics underlying WTC, and help us to understand the nature of the restraints placed on action in situ. At any moment a learner might feel both motivated to learn and inhibited by anxiety because of the culmination of converging, conflicting processes. Such processes lead to both approach and avoidance tendencies, operating simultaneously, waxing and waning in salience from moment to moment. These moments of ambivalence, in essence, capture the difficulty that learners face in crossing their individual Rubicon described previously. Much of the current SLA literature on language anxiety and motivation reflects trait-level processes where generalizations are the goal, and exceptions to the rule are considered error variance or noise (Allen \& Herron, 2003). The literature on the psychology of L2 communication would benefit a great deal from studying specific, conflicted moments in time.

As an example of how such moments might be captured, Wen and Clément (2003) recently have extended the pyramid model to include explicitly this notion of situated restraints in a Chinese context. They argued that, after an individual forms a WTC, Chinese culture demands an additional set of restraining forces based on the sense of responsibility to the collectivity and on deference to authority. The strength of the restraining forces on the moment of communication helps to explain the well-known Chinese reluctance to speak, and the value placed on thoughtful silence. People in other cultures, for example, in the United States, on average appear to be far more willing to speak (Sallinen-Kuparinen, McCroskey, \& Richmond, 1991). Therefore, differences in intercultural communication lie partially in the culturally conditioned restraining forces on communication. Such intergroup differences can become prominent features of social interaction when members from different cultures communicate with each other.

Yashima (2002) studied WTC in such a situation with her work on Japanese student sojourners visiting the United States, although her work focused on a time frame of several months, rather than changes in WTC from moment to moment. The purpose of the sojourner students' travel was to live with host families and attend school in the United States, enhancing their L2 skills in English. Students who left Japan with higher WTC in the L2 reported having more contact with the host families and speaking more frequently in their new schools. These interactions were associated with more positive outcomes from the sojourn, including better adjustment and satisfaction with the experience. It should be noted that in examining the cumulative effects of WTC, we have moved to a situation-specific level of conceptualization, and are considering a period spanning several months.

These points lead to a final kernel of wisdom: Future research in SLA should focus on the momentary restraining forces that come into play when a speaker is choosing whether or not to initiate communication.

\section{A NOTE ON METHODOLOGY}

A better understanding of the dynamics of the moment-to-moment processes that both lead to and prevent action will require a set of methodologies that are suited to the task. The methods currently in use, based on correlation or analysis of variance, offer a snapshot of the processes under study. This snapshot has value, but the action necessarily is stopped when we take the picture. As an analogy, imagine a photograph taken during play of any sport: football, baseball, or tennis, for example. The image tells us a great deal about that sport: the number of players, their equipment, the type of playing surface, the size and shape of the ball being used, and so on. The action of the game, however, is frozen in the photo. To understand how the game is played, we must set the process in motion. Methods based on correlation are analogous to the photograph, by taking variables measured at a particular moment in time and examining their covariance. Analysis of variance takes a similar approach by setting defined levels of an independent variable and observing the effects on samples of a dependent variable, at a particular time. In both cases, the methods freeze the process at a moment for detailed study. Methods using repeated measures allow us to begin to see the process in motion, but are limited to the number and timing of the measurements. Qualitative methodologies have the advantage of providing rich descriptions of dynamic process in participants' own terms. However, qualitative processes are limited by both their idiosyncratic focus (where generalization is not a concern, see 
Maxwell, 2005) and the difficulties of biases in reporting memories (Loftus, 1980), especially from autobiographical memory. These difficulties are likely to become more acute as time elapses between the occurrence of an event and describing that event to a researcher. Of particular relevance to the present discussion is the fading affect bias whereby negative emotions associated with events fade from memory faster than positive emotions associated with the same events (Ritchie et al., 2006).

We need a methodology that is focused on dynamic changes in the processes that underlie communication at a particular moment. There is obvious difficulty in asking communicators to judge their anxiety, motivation, competence, and so on, since they are deciding whether to initiate communication. A solution to this methodological issue likely will require methods wherein the measurements are taken immediately after the communication event. One possibility is recording L2 conversations followed by a form of stimulated recall (Gass \& Mackey, 2000) in which the participants review the conversation and report on the salient internal emotional and cognitive processes they experienced. This methodology could take advantage of the opportunities to use either the computer, or audio- and videorecording equipment, all commonly found in language laboratories to study conversations of various types. For example, spontaneous conversations between peers, between more experienced and less experienced learners, or between L1 and L2 speakers in a language learning classroom could be recorded and reviewed with the participants. As a second example, the procedure might be applied to studying the process of cooperating in computer-mediated communication, such as Internet chat conversations, where the written record could be reviewed and the participants queried about their choices of when they decided to write a comment. Finally, experimental methodologies also could be developed to manipulate conditions systematically where the focus is on the moments leading to the initiation of communication. A body of research developed in this broadly defined area holds the potential to provide a more satisfactory answer to the question of why some L2 learners choose not to speak. A significant, added advantage of the volitional approach advocated in this article is the potential to integrate more fully physiological and, in particular, neurobiological (see Porges, 2003; Porges, 2007; Schumann et al., 2004) processes into theories of L2 communication (see also Beatty \&
McCroskey, 1998; Beatty, McCroskey \& Valencic, 2001).

\section{CONCLUSION AND FUTURE DIRECTIONS}

The present discussion began by asking why some people seek and others avoid L2 communication. There is no doubt that both language anxiety and language learning motivation play a role, and their effects can be observed over time. Previous research has devoted a great deal of attention to describing the long-term patterns and relationships among trait-level or situationspecific variables that are observed all over the world. But if we approach the question using a very narrow time frame, that is, if we examine the process of creating a WTC at a specific time with a specific person, we see a fascinating, complex process. The longer term patterns have a role to play, but the interplay of the features of the situation with the psychology of the individual speaker takes on a primary role in this paradigm. The volitional act of speaking requires the coordination of a set of driving and restraining forces that may operate with or without the speaker's explicit awareness.

Future research directions that investigate the moment of decision are likely to produce some very interesting results that complement existing research. We have yet to develop a set of methodologies to study the affective changes at the moment communication begins. It seems clear that those methods will be a combination of quantitative and qualitative approaches, as has been advocated in the literature on motivation (Ushioda, 2001). Ideally, this research can be done with sensitivity to the varieties of expectations for communication in various cultures (Wen \& Clément, 2003). Perhaps the most important decision language learners face is whether or not to use their incipient skills when the opportunity arises, inside or outside the classroom. The forces that hold a person back when the moments of decision come along potentially hold the key to unlocking the secrets of the language learners who are not necessarily language speakers.

\section{ACKNOWLEDGMENTS}

This research was supported by a grant from the Social Science and Humanities Research Council of Canada. This manuscript is based on a presentation given at EURO SLA 2005, Dubrovnik, Croatia. I extend my sincere appreciation to Sean Mackinnon and R. C. 
Gardner, as well as the $M L J$ editor and anonymous reviewers, for their comments on this manuscript.

\section{REFERENCES}

Agazarian, Y., \& Gantt, S. (2003). Phases of group development: Systems-centered hypotheses and their implication for research and practice. Group Dynamics: Theory, Research and Practice, 7, 238252.

Ahmed, S. M. (1990). Psychometric properties of the boredom proneness scale. Perceptual and Motor Skills, 71, 963-966.

Aida, Y. (1994). Examination of Horwitz, Horwitz, \& Cope's construct of foreign language anxiety: The case of students of Japanese. Modern Language Journal, 78, 155-168.

Ajzen, I., \& Fishbein, M. (1980). Understanding attitudes and predicting social behavior. Englewood Cliffs, NJ: Prentice Hall.

Alalou, A. (2001). Reevaluating curricular objectives using students' perceived needs: The case of three language programs. Foreign Language Annals, 34, 453-469.

Allard, R., \& Landry, R. (1994). Subjective ethnolinguistic vitality: A comparison of two measures. International Journal of the Sociology of Language, 108, 117-144.

Allen, H. W., \& Herron, C. (2003). A mixedmethodology investigation of the linguistic and affective outcomes of summer study abroad. Foreign Language Annals, 36, 370-385.

Baker, S. C., \& MacIntyre, P. D. (2000). The role of gender and immersion in communication and second language orientations. Language Learning, 50, 311-341.

Beatty, M. J., \& McCroskey, J. C. (1998). Interpersonal communication as temperamental expression: A communibiological paradigm. In J. C. McCroskey, J. A. Daly, M. M. Martin, \& M. J. Beatty (Eds.), Communication and personality: Trait perspectives (pp. 41-68). Cresskill, NJ: Hampton.

Beatty, M. J., McCroskey, J. C., \& Valencic, K. M. (2001). The biology of communication: A communibiological perspective. Cresskill, NJ: Hampton Press.

Burgoon, J. K. (1976). The unwillingness-tocommunicate scale: Development and validation. Speech Monographs, 43, 60-69.

Clark, J. L. D. (1981). Language. In T. S. Barrows (Ed.), A survey of global understanding: Final report (pp. 87-100). New Rochelle, NY: Change Magazine Press.

Clément, R. (1986). Second language proficiency and acculturation: An investigation of the effects of language status and individual characteristics. Journal of Language and Social Psychology, 5, 271290.

Clément, R., Dörnyei, Z., \& Noels, K. (1994). Motivation, self-confidence and group cohesion in the foreign language classroom. Language Learning, 44, 417448.

Clément, R., \& Gardner, R. C. (2001). Second language mastery. In H. Giles \& W. P. Robinson (Eds.), Handbook of language and social psychology (pp. 489-504). London: Wiley.

Crookes, G., \& Schmidt, R. W. (1991). Motivation: Reopening the research agenda. Language Learning, 41, 469-512.

Dörnyei, Z. (1990). Conceptualizing motivation in foreign-language learning. Language Learning, 40, 45-78.

Dörnyei, Z. (1994). Motivation and motivating in the foreign language classroom. Modern Language Journal, 78, 273-284.

Dörnyei, Z. (2001). Motivational strategies in the language classroom. Cambridge: Cambridge University Press.

Dörnyei, Z. (2003). Attitudes, orientations, and motivations in language learning: Advances in theory, research, and applications. In Z. Dörnyei (Ed.), Attitudes, orientations and motivations in language learning (pp. 3-32). Oxford: Blackwell.

Dörnyei, Z. (2005). The psychology of the language learner: Individual differences in second language acquisition. London: Erlbaum.

Eysenck, S., \& Zuckerman, M. (1978). The relationship between sensation-seeking and Eysenck's dimensions of personality. British Journal of Psychology, 69, 483-487.

Frantzen, D., \& Magnan, S. S. (2005). Anxiety and the true beginner-false beginner dynamic in beginning French and Spanish classes. Foreign Language Annals, 38, 171-190.

Gardner, R. C. (1985). Social psychology and second language learning: The role of attitudes and motivation. London: Edward Arnold.

Gardner, R. C. (2001, February). Integrative motivation: Past, present and future. Paper presented at the Distinguished Lecturer Series, Temple University Japan, Tokyo and Osaka. Retrieved March 14, 2007 from http://publish. uwo.ca/ gardner/GardnerPublicLecture1.pdf

Gardner, R. C., \& Lambert, W. E. (1959). Motivational variables in second language acquisition. Canadian Journal of Psychology, 13, 266-272.

Gardner, R. C., \& Lambert, W. E. (1972). Attitudes and motivation in second language learning. Rowley, MA: Newbury House.

Gass, S. M., \& Mackey, A. (2000). Stimulated recall methodology in second language research. Mahwah, NJ: Erlbaum.

Giles, H., \& Byrne, J. L. (1982). An intergroup approach to second language acquisition. Journal of Multilingual and Multicultural Development, 1, 17-40.

Gregersen, T. S. (2003). To err is human: A reminder to teachers of language-anxious students. Foreign Language Annals, 36, 25-32.

Horwitz, E. K. (1986). Preliminary evidence for the reliability and validity of a foreign language anxiety scale. TESOL Quarterly, 20, 559-562. 
Horwitz, E. K., Horwitz, M. B., \& Cope, J. A. (1986). Foreign language classroom anxiety. Modern Language Journal, 70, 125-132.

James, W. (1890). The principles of psychology (Vol. 2). New York: Henry Holt.

Jülkunen, K. (1989). Situation- and task-specific motivation in foreign language learning and teaching. Joensuu, Finland: University of Joensuu.

Jülkunen, K. (2001). Situation and task specific motivation in foreign language learning. In Z. Dörnyei \& R. Schmidt (Eds.), Motivation and second language learning (pp. 29-42). Honolulu: University of Hawai'i Press.

Lewin, K. (1951). Field theory in the social sciences: Selected theoretical papers. New York: Harper.

Loftus, E. F. (1980). Memory. Reading, MA: AddisonWesley.

MacDonald, J. R., Clément, R., \& MacIntyre, P. D. (2003). Willingness to communicate in a L2 in a bilingual context: A qualitative investigation of anglophone and francophone students. Unpublished manuscript, Cape Breton University, Sydney, Nova Scotia, Canada.

MacIntyre, P. D. (1999). Language anxiety: A review of the research for language teachers. In D. J. Young (Ed.), Affect in foreign language and second language learning: A practical guide to creating a low-anxiety classroom atmosphere (pp. 24-45). Boston: McGrawHill.

MacIntyre, P. D., Babin, P. A., \& Clément, R. (1999). Willingness to communicate: Antecedents and consequences. Communication Quarterly, 47, 215-229.

MacIntyre, P. D., Baker, S., Clément, R., \& Donovan, L. (2002). Sex and age effects on willingness to communicate, anxiety, perceived competence, and L2 motivation among junior high school French immersion students. Language Learning, 52, 537564.

MacIntyre, P. D., \& Charos, C. (1996). Personality, attitudes, and affect as predictors of second language communication. Journal of Language and Social Psychology, 15, 3-26.

MacIntyre, P. D., Clément, R., Dörnyei, Z., \& Noels, K.A. (1998). Conceptualising willingness to communicate in a L2: A situational model of L2 confidence and affiliation. Modern Language Journal, 82, 545562.

MacIntyre, P. D., Clément, R., \& Noels, K. A. (2007). Affective variables, attitude and personality in context. In D. Ayoun (Ed.), Handbook of French applied linguistics (pp. 270-298). Philadelphia: John Benjamins.

MacIntyre, P. D., \& Gardner, R. C. (1989). Anxiety and second-language learning: Toward a theoretical clarification. Language Learning, 39, 251-275.

MacIntyre, P. D., \& Gardner, R. C. (1991). Investigating language class anxiety using the focused essay technique. Modern Language Journal, 75, 296304.

MacIntyre, P. D., \& Gardner, R. C. (1994a). The subtle effects of language anxiety on cognitive processing in the second language. Language Learning, 44, 283-305.

MacIntyre, P. D., \& Gardner, R. C. (1994b). The effects of induced anxiety on cognitive processing in computerised vocabulary learning. Studies in Second Language Acquisition, 16, 1-17.

Masgoret, A.-M., \& Gardner, R. C. (2003). Attitudes, motivation and second language learning: A metaanalysis of studies conducted by Gardner and associates. In Z. Dörnyei (Ed.), Attitudes, orientations, and motivations in language learning (pp. 167210). Oxford, England: Blackwell.

Maxwell, J. A. (2005). Qualitative research design (2nd ed.). Thousand Oaks, CA: Sage.

McCroskey, J. C., \& Baer, J. E. (1985, November). Willingness to communicate: The construct and its measurement. Paper presented at the annual convention of the Speech Communication Association, Denver, CO.

McCroskey, J. C., \& Richmond, V. P. (1991). Willingness to communicate: A cognitive view. In M. BoothButterfield (Ed.), Communication, cognition, and anxiety (pp. 19-37). Newbury Park, CA: Sage.

Noels, K. A. (2001). New orientations in language learning motivation: Towards a model of intrinsic, extrinsic and integrative orientations. In Z. Dörnyei \& R. Schmidt (Eds.), Motivation and second language acquisition (pp. 43-68). Honolulu: University of Hawai'i, Second language Teaching and Curriculum Center.

Noels, K. A. (2005). Orientations to learning German: Heritage language background and motivational processes. Canadian Modern Language Review, 62, 285-312.

Onwuegbuzie, A. J., Bailey, P., \& Daley, C. E. (2000). The validation of three scales measuring anxiety at different stages of the foreign language learning process: The input anxiety scale, the processing anxiety scale, and the output anxiety scale. Language Learning, 50, 87-117.

Oxford, R. L., \& Shearin, J. (1994). Language learning motivation: Expanding the theoretical framework. Modern Language Journal, 78, 12-28.

Porges, S. W. (2003). The polyvagal theory: Phylogenetic contributions to social behavior. Physiology $\mathcal{E} \mathrm{B} e-$ havior, 79, 503-513.

Porges, S. W. (2007). The polyvagal perspective. Biological Psychology, 74, 116-143.

Price, M. L. (1991). The subjective experience of foreign language anxiety: Interviews with highly anxious students. In E. K. Horwitz \& D. J. Young (Eds.), Language Anxiety (pp. 101-108). Englewood Cliffs, NJ: Prentice-Hall.

Ritchie, T. D., Skowronski, J. J., Wood, S. E., Walker, W. R., Vogl, R. J., \& Gibbons, J. (2006). Event selfimportance, event rehearsal and the fading affect bias in autobiographical memory. Self and Identity, 5, 172-195.

Sallinen-Kuparinen, A., McCroskey, J. C., \& Richmond, V. P. (1991). Willingness to communicate, 
communication apprehension, introversion, and self-reported communication competence: Finnish and American comparisons. Communication Research Reports, 8, 55-64.

Schumann, J. H. (1986). Research on the acculturation model for second language acquisition. Journal of Multilingual and Multicultural Development, 7, 379392.

Schumann, J. H. (1997). The neurobiology of affect in language. Malden, MA: Blackwell.

Schumann, J., Crowell, S., Jones., N., Lee, N., Scuchert, S., \& Wood, A. (2004). The neurobiology of learning: Perspectives from second language acquisition. Mahwah, NJ: Erlbaum.

Scovel, T. (1978). The effect of affect on foreign language learning: A review of anxiety research. Language Learning, 28, 129-142.

Spada, N. (1986). The interaction between types of content and type of instruction: Some effects on the L2 proficiency of adult learners. Studies in Second Language Acquisition, 8, 181-199.

Spielberger, C. D. (1983). Manual for the state-trait anxiety inventory (form Y). Palo Alto, CA: Consulting Psychologists Press.

Ushioda, E. (2001). Language learning at university: Exploring the role of motivational thinking. In Dörnyei \& R. Schmidt (Eds.), Motivation and second language acquisition (Tech. Rep. No. 23, pp.
93-125). Honolulu: University of Hawai'i, Second Language Teaching and Curriculum Center.

Vogely, A. J. (1998). Listening comprehension anxiety: Students' reported sources and solutions. Foreign Language Annals, 31, 67-80.

Wen, W. P., \& Clément, R. (2003). A Chinese conceptualization of willingness to communicate in ESL. Language, Culture and Curriculum, 16, 18-38.

Wilson, G. (1978). Introversion/extraversion. In H. London \& J. E. Exner (Eds.), Dimensions of personality (pp. 217-261). New York: John Wiley.

Wilson, R. G., \& Lynn, R. (1990). Personality, intelligence components and foreign language attainment. Educational Psychology, 10, 57-71.

Yashima, T. (2002). Willingness to communicate in a second language: The Japanese EFL context. Modern Language Journal, 86, 54-66.

Yashima, T., Zenuk-Nishide, L., \& Shimizu, K. (2004). The influence of attitudes and affect on willingness to communicate and second language communication. Language Learning, 54, 119-152.

Young, D. J. (1991). Creating a low-anxiety classroom environment: What does language anxiety research suggest? Modern Language Journal, 75, 426-439.

Zakahi, W. R., \& McCroskey, J. C. (1989). Willingness to communicate: A potential confounding variable in communication research. Communication Reports, 2, 96-104.

\section{Forthcoming in The Modern Language Journal, 92, 1 Under the editorship of Leo van Lier}

Russell Rosen. "American Sign Language as a Foreign Language in U.S. Secondary Schools: State of the Art"

Chieh-Fang Hu. "Rate of Acquiring and Processing L2 Color Words in Relation to L1 Phonological Awareness"

Eve Zyzik \& Charlene Polio. "Content and Language Goals in Conflict? Incidental Focus on Form in University Spanish Literature Courses"

Meihua Liu \& Jane Jackson. "An Exploration of Chinese EFL Learners' Unwillingness to Communicate and Foreign Language Anxiety"

Jacek Rysiewicz. "Cognitive Profiles of (Un)successful EFL Learners: A Cluster Analytical Study"

Virginia Scott \& María José de la Fuente. "What's the Problem? L2 Learners' Use of L1 During Consciousness-Raising, Form-Focused Tasks

Youjin Kim. "The Contribution of Collaborative and Individual Tasks to the Acquisition of L2 Vocabulary" 